Fast breeder

\section{reactors delayed until after 2000}

A declining enthusiasm for nuclear power in the US has led the Carter administration to stretch out still further research and development efforts leading to the deployment of fast breeder nuclear reactors. These are not now planned to come into commercial use until well beyond 2000 .

In his budget request to Congress two weeks ago for the fiscal year 1981, President Carter reaffirmed his previous determination to halt construction of the liquid metal fast breeder demonstration project at Clinch River in Tennessee, a move so far resisted by Congress.

At the same time, however, the President has also recommended other broad cuts in the breeder development programme not proposed in previous years. This is in line with a decision taken late last year to stretch out the LMFBR programme and defer building breeder reactors, previously expected to come into use in the 1990s.

Administration officials are thought to believe that, given the current uncertainties surrounding the future of nuclear power, following the Three Mile Island accident, as well as adequate domestic supplies of uranium, it would probably be impossible at present for a new reactor type to be produced and licensed in the US. The Department of Energy had asked the White House to keep breeder funding at the 1980 level, apart from Clinch River.

Recommended cuts in the breeder programme include reducing support for LMFBR technology from $\$ 140$ million to $\$ 80$ million in 1981 , and cutting out completely further development of the gascooled breeder reactor, currently being supported as a back-up programme.

Funding for research and development in fuel processing technologies for breeders is proposed to be reduced from $\$ 49.5$ to $\$ 12$ million, and plans for a conceptual design study for a larger scale plant than the Clinch River project will be terminated.

Overall funding for the breeder programme will, if Congress agrees, be cut from $\$ 761$ million to $\$ 384$ million. What actually happens, however, will depend on the outcome of the conflict over the Clinch River funding; until this is resolved, the administration is facing severe difficulties in producing a balanced programme for nuclear fission research.

Domestic cutbacks in the breeder programme have heightened the enthusiasm of energy officials for cooperation with other countries. In particular an exchange of agreement was signed with France at the beginning of December, through which it is hoped to work with French scientists and engineers.

Canada

\title{
Election candidates asked for science funding commitments
}

\author{
Canadian scientists are mounting an active campaign to inform \\ candidates in next week's general election of the need to increase \\ support for university research. David Dickson reports
}

Soon after Canada's nine-month-old Conservative government resigned last month, scientists at the University of Toronto placed a letter on campus noticeboards asking for volunteers to investigate the attitudes of local candidates in next week's general election towards research funding.

Each volunteer is being equipped with a background kit on federal R\&D policies prepared by groups such as the Canadian Association of University Teachers and the Canadian Federation of Biological Societies, and then assigned to candidates in one of Toronto's 23 ridings (constituencies).

The idea is to discover whether in general terms a candidate is prepared to support increased funding for research and development - or to provide information to those who have not considered the issue before - and also to report back on any commitments that a candidate may make.

These are checked back with the candidate's party, and noted for future use. "We are using this as a device to wheedle commitments, and if we get the commitments we are going to nail them," says Dr Ron Clarke, director of the University of Toronto's Office of Research Administration.

The scientists' campaign is being organised jointly by the CAUT, the CFBS, and other professional societies such as the Canadian Association of Physicists. With lobbying planned in more than 50 election districts, it is the latest tactic in an aggressive grass-roots strategy waged over the past few years to focus political attention on the relative lack of funding for university research.

Argument has been focused on the fact that government spending on basic research fell from $0.1 \%$ to $0.07 \%$ of the gross national product between 1969 and 1979 , less than half that of most industrialised nations.

Responding to such criticisms, the Liberal government made a commitment to increase overall $R \& D$ spending to $1.5 \%$ GNP by 1983 shortly before losing power last year; and in November, $\mathrm{Mr}$ Howard Grafftey, Minister of State for Science and Technology, announced that the Conservative government proposed to increase the funding of the Natural Sciences and Engineering Research Council by $32 \%$, to a total of $\$ 159.8$ million, in the fiscal year 1980-81.
This increase was contained in the total budget figures over which the Conservative government was defeated in Parliament in December. But last week, with the election campaign in full swing, $\mathrm{Mr}$ Grafftey announced that NSERC's budget would be increased still further, to a total of $\$ 162.6$ million.

At the same time, Mr Grafftey announced that the budget of the Social Sciences and Humanities Research Council would be increased by $16.2 \%$, and that of the Medical Research Council by $17.4 \%$ bringing the total increase for the three research councils to $26.4 \%$.

Budgetary levels for the councils approved by the Cabinet are for the first year of five-year plans which each has submitted. The increased funding has been welcomed by the scientific community, which feels that, whichever party wins next week's election, it will be difficult to go back to the lower increases previously projected. But there is concern over whether the increased level of funding will be maintained into future years.

The Party has publicly committed itself to an eventual target of spending $2.5 \%$ of the gross national product on $R \& D$, although without being specific about timing. The small but growing New Democratic Party - which could hold the balance of power in a close ballot - has adopted the ambitious target of $4 \%$ by 1990 and $2.5 \%$ by 1983 .

Many scientists doubt whether these are realistic targets, given the rapid sustained growth in funding that they would require. But there is determination to keep pressure on the new government to confer stability to the Canadian research effort.

One element of concern is that the new government should retain a minister with full-time responsibilities for science and technology. Another is that the provinces should play their part in the national effort to stimulate R\&D; some have recently been criticised for diverting federal funds allocated - although not mandated - for the support of further and higher education.

In Toronto, the scientists claim their grass-roots lobbying towards such objectives is beginning to pay-off. Already one Liberal ex-Cabinet member has said his party, if elected, will appoint a full-time minister for science and technology. But what actually happens after election day remains to be seen. 